\title{
INFLUENCE OF TEMPERATURE UPON THE MOBILIZATION OF NITROGEN IN PEAT
}

\author{
By \\ Armi Kaila, JaAkko Köylijärvi and Erkki Kivinen \\ University of Helsinki, Department of Agricultural Chemistry
}

Received 2th February 1953

In connection with a more extensive work on the mobilization of nitrogen in peat soils of Northern Finland attention was paid to the influence of temperature upon the changes in the nitrogen complex. Although there is not much possibility to control the temperature of peat soils in practice, it seemed, however, desirable to find out whether the microflora inhabiting the soil at higher temperatures could attack the organic nitrogen compounds of peat with better results than the population living there under less favourable conditions. In addition to the changes in nitrogen compounds brought about by microbial activity the burning over of the surface peat can be expected to cause a considerable mineralization of peat nitrogen.

In order to get some information on the biological and chemical mobilization of nitrogen in peat at various temperatures preliminary experiments under laboratory conditions were arranged. The chief results of these experimental series are reported in the present paper.

\section{Experimental procedure}

Peat samples. Two samples of peat were used in the experiments: a Sphagnumsedge peat (SCp) and a Bryales-sedge peat (BCp). The SCp-sample was taken from a wet treeless oligotrophic bog in Rovaniemi and the $\mathrm{BC}$-sample from a Scorpidiumfen in Alatornio.

In the hollows of the bog the surface vegetation chiefly consisted of Carex magellanica and Menyanthes trifoliata with a few individuals of Carex lasiocarpa, Carex chordorrhiza and Equisetum fluvitiale. In the surface vegetation of the fen Scorpidium scorpioides predominated.

The degree of decomposition was low in both the peat samples corresponding to the grades $\mathrm{H}_{3-4}$ in the $\mathrm{SC}$-peat and $\mathrm{H}_{2-3}$ in the $\mathrm{BC}$-peat (9). 
The samples were air-dried at $15-18^{\circ} \mathrm{C}$ and ground in a Wiley mill The acidity of SC-peat in water suspension was $\mathrm{pH} 4.7$ and that of the BC-peat 4.8 The weights of volume were 0.26 and 0.21 , respectively. The dry matter of the SC-peat contained $2.9 \%$ nitrogen and that of the BC-peat $2.5 \%$. The chemical composition of these peat samples analyzed by the proximate method of WAKSMAN, modified by SPRINGER (13) was as follows, expressed as a percentage of air-dry matter:

$\begin{array}{lrr} & \mathrm{SCp} & \mathrm{BCp} \\ \text { Moisture } & 9.1 & 9.3 \\ \text { Ash } & 4.1 & 4.7 \\ \text { Loss on ignition } & 86.8 & 86.0 \\ & & \\ \text { Ether soluble material } & 5.7 & 3.2 \\ \text { Ethanol-soluble } & 2.8 & 2.0 \\ \text { Water-soluble organic matter } & 2.6 & 1.9 \\ \text { HCl-soluble material } & 22.9 & 23.8 \\ \quad \text { Hemicelluloses } & 10.7 & 12.1 \\ \mathrm{H}_{2} \mathrm{SO}_{4} \text {-soluble material } & 12.7 & 22.7 \\ \quad \text { Cellulose } & 5.9 & 12.5 \\ \text { Insoluble material } & 41.5 & 35.0 \\ \quad \text { Lignins》 } & 34.2 & 27.1\end{array}$

The not very marked differences between the chemical compositions of these samples suggest that the SC-peat represents a somewhat higher degree of decomposition than the BC-peat: according to our present knowledge the disappearence of cellulose and the increase in the content of insoluble material are characteristic to the advance of decomposition.

In connection with the analyses of the organic matter also the amount of total nitrogen in various fractions was determined:

\begin{tabular}{llccr} 
& \multicolumn{5}{c}{$\begin{array}{c}\text { Nitrogen in percentage of dry matter } \\
\text { in the peat }\end{array}$} & \multicolumn{2}{c}{ in the fraction } \\
& $\mathrm{SCp}$ & $\mathrm{BCp}$ & $\mathrm{SCp}_{\mathrm{p}}$ & $\mathrm{BCp}$ \\
Ether-soluble & 0.08 & 0.07 & 1.3 & 2.0 \\
Ethanol-soluble & 0.08 & 0.08 & 2.6 & 3.6 \\
Water-soluble & 0.15 & 0.10 & 4.6 & 4.4 \\
Acid-soluble & 1.71 & 1.81 & 5.3 & 4.8 \\
Insoluble & 0.88 & 0.44 & 1.9 & 1.1
\end{tabular}

The SC-peat has a larger amount of its nitrogen in the insoluble lignin-humus fraction than the $\mathrm{BC}$-peat, a fact that agrees well with the probably higher degree of decomposition of the former.

Plan of experiments. In order to compare the ability of psychrophilic, mesophilic and thermophilic microflora to mobilize the peat nitrogen an incubation experiment was arranged:

$30 \mathrm{~g}$ of air-dry, ground peat was weighed in $1 / 41$ glass-jars. One half of the samples were limed in order to decrease the acidity to about $\mathrm{pH}$. The amounts 
of $\mathrm{CaCO}_{3}$ added corresponded to $1.4 \%$ and $1.2 \%$ of the air-dry material in the $\mathrm{SC}$-peat and the $\mathrm{BC}$-peat, respectively. The samples were moistened to $70 \%$ of their water holding capacity, and mixed well. The bottles were loosely covered with cork stoppers and incubated at $5^{\circ}, 20^{\circ}, 35^{\circ}, 50^{\circ}$, or $65^{\circ}$ for 100 days.

The chemical mobilization of peat nitrogen by heat was studied by some simple experiments where the dry or moist peat samples were treated at various temperatures. The moist treatment was performed at $75^{\circ}, 100^{\circ}$ and $120^{\circ}$, the time of heating being two hours. The dry samples were heated for three hours at $50^{\circ}$, $75^{\circ}, 100^{\circ}, 125^{\circ}, 150^{\circ}$, or $200^{\circ}$.

Analytical methods. A $10 \%$ solution of potassium chloride was used in the extraction of $\mathrm{NH}_{4}$-nitrogen. The air-dried 5 g-samples were first shaken for $1 / 2$ hour in $100 \mathrm{ml}$ of the solution and, after filtration, washed twice with $25 \mathrm{ml}$ of the liquid. The ammonia in the extract was determined by distillation with MgO.

Nitrate-nitrogen was estimated in $\mathrm{CaSO}_{4}$-extracts by the modified method of BERGE (1) using a photoelectric colorimeter. The presence of nitrite-nitrogen was observed only ocularly: the intensity of the red colour in the $\mathrm{CaSO}_{4}$-extracts produced by the GRIESs reagents was compared with that of standard solutions.

The acid-insoluble nitrogen supposed to represent the nitrogen in the ligninhurnus complex was determined as total nitrogen in the insoluble residue of the hydrolysis brought about by treating the air-dry sample with $80 \%$ sulfuric acid for $2 \frac{1}{2}$ hours and boiling it in diluted acid under reflux condensor for 5 hours.

The $\mathrm{pH}$-values were determined in water suspensions using a quinhydroneelectrode, or from fresh material with a glass electrode.

\section{Results}

In the incubation experiment no inoculation of active decomposers was employed. Thus the biological changes in the composition of peat samples during the incubation at various temperatures were brought about by representatives of common microorganisms that could adapt themselves to grow under these different conditions. Losses of peat dry matter at the end of the incubation period were:

\begin{tabular}{crrrr} 
& \multicolumn{2}{c}{ in the SC-peat } & \multicolumn{2}{c}{ in the BC-peat } \\
incubated & without lime & with lime & without lime & with lime \\
at $5^{\circ}$ & $1.5 \%$ & $1.5 \%$ & $7 \%$ & $5 \%$ \\
$20^{\circ}$ & $8 \%$ & $3 \%$ & $10 \%$ & $8 \%$ \\
$35^{\circ}$ & $7 \%$ & $7 \%$ & $10 \%$ & $10 \%$ \\
$50^{\circ}$ & $13 \%$ & $17 \%$ & $13 \%$ & $13 \%$ \\
$65^{\circ}$ & $18 \%$ & $18 \%$ & $17 \%$ & $20 \%$
\end{tabular}

In view of the fact that the decomposition period was more than three months, the destruction of organic matter has not been very marked except in the range of thermophilic microflora. This, of course, is due to the high resistance of the carbon compounds even in these very slightly humified samples, or to the shortage of some essential nutrial elements as phosphorus or potassium. It is of particular 
interest to note that the acidity was not a limiting factor, since the effect of liming was negligible.

The acidity of the incubated samples was determined both from the fresh material and from the water-suspensions $(1: 4)$ of the dried samples. In the fresh samples the $\mathrm{pH}$-values were as follows:

\begin{tabular}{rcccc} 
& \multicolumn{2}{c}{ SCp } & \multicolumn{2}{c}{ BCp } \\
incubated at $5^{\circ}$ & 4.56 & 6.08 & 4.75 & 6.53 \\
$20^{\circ}$ & 3.93 & 4.86 & 4.70 & 5.38 \\
$35^{\circ}$ & 4.79 & 5.85 & 4.95 & 5.95 \\
$50^{\circ}$ & 4.80 & 5.72 & 5.03 & 6.10 \\
$65^{\circ}$ & 3.20 & 5.58 & 4.79 & 6.30
\end{tabular}

The corresponding values for the dried samples in the untreated series were at a somewhat higher level:

\begin{tabular}{ccccc}
\multicolumn{2}{c}{ SCp } & \multicolumn{2}{c}{ BCp } \\
incubated & untreated & limed & untreated & limed \\
at $5^{\circ}$ & 5.00 & 5.96 & 4.96 & 6.19 \\
$20^{\circ}$ & 4.48 & 5.18 & 5.12 & 5.77 \\
$35^{\circ}$ & 5.18 & 5.92 & 5.34 & 5.95 \\
$50^{\circ}$ & 5.22 & 5.65 & 5.45 & 6.01 \\
$65^{\circ}$ & 3.99 & 5.68 & 5.27 & 6.00
\end{tabular}

Particularly disturbing are the low $\mathrm{pH}$-values obtained for the samples incubated at $20^{\circ}$. Yet, this unexpected result can be explained partly at least, on the basis of the accumulation of nitrate-nitrogen in these samples. The acidity of the $\mathrm{SC}$-peat incubated at $65^{\circ}$ may have its origin in the same phenomenon, but probably also other factors are involved.

The amounts of various forms of mineral nitrogen in the incubated and original samples are reported in Table 1 . The fact must be taken into consideration that these data represent the net results of mineralization and biological immobilization of nitrogen. Thus, the large amounts of mineral nitrogen in the samples incubated at the higher temperatures do not merely indicate an intensive destruction of organic nitrogen compounds but also a less efficient biological absorption of nitrogen under these conditions as compared to that occuring at lower temperatures. This is due to the fact that microorganisms live, die, and decompose much more rapidly at higher temperatures, on account of which the nitrogen is changed more rapidly within the microbial cycle (15). Also the different composition of microbial population at higher and at lower temperatures is a significant factor. The fungal flora that is known to utilize a relative large amount of nitrogen in the synthesis of new cell substance is absent in the range of thermophilic population or only scarcely represented $(5,16)$.

In the untreated series of SC-peat the amounts of ammonia and total mineral nitrogen show an increase with a rising temperature, whereas the nitrate formation has its maximum at $20^{\circ}$. In the limed series a minimum quantity of ammonia nitrogen 
Table 1. Mineral nitrogen in the incubated samples (Expressed as ppm of dry matter)

\begin{tabular}{|c|c|c|c|c|c|c|c|c|}
\hline \multirow{2}{*}{$\begin{array}{c}\text { Incubated } \\
\text { at }\end{array}$} & \multicolumn{2}{|c|}{$\mathrm{NH}_{4}-\mathrm{N}$} & \multicolumn{2}{|c|}{$\mathrm{NO}_{2}-\mathrm{N}$} & \multicolumn{2}{|c|}{$\mathrm{NO}_{3}-\mathrm{N}$} & \multicolumn{2}{|c|}{ Total mineral $\mathrm{N}$} \\
\hline & 0 & $\mathrm{CaCO}_{3}$ & 0 & $\mathrm{CaCO}_{3}$ & 0 & $\mathrm{CaCO}_{3}$ & 0 & $\mathrm{CaCO}_{3}$ \\
\hline SC-peat & & & & & & & & \\
\hline Original & 330 & & 5 & & 30 & & 370 & \\
\hline $5^{\circ}$ & 690 & 670 & 5 & 5 & 30 & 70 & 720 & 750 \\
\hline $20^{\circ}$ & 780 & 220 & 8 & 2 & 230 & 480 & 1020 & 700 \\
\hline $35^{\circ}$ & 1410 & 1050 & 5 & trace & 70 & 100 & 1490 & 1150 \\
\hline $50^{\circ}$ & 2250 & 2460 & trace & 0 & - & - & - & - \\
\hline $65^{\circ}$ & 5960 & 4860 & trace & 0 & 200 & 160 & 6160 & 5020 \\
\hline BC-peat & & & & & & & & \\
\hline Original & 390 & & trace & & 50 & & 440 & \\
\hline $5^{\circ}$ & 650 & 550 & 5 & 5 & 30 & 30 & 680 & 590 \\
\hline $20^{\circ}$ & 480 & 290 & 2 & 5 & 60 & 190 & 540 & 480 \\
\hline $35^{\circ}$ & 740 & 590 & 2 & 5 & 40 & 40 & 780 & 630 \\
\hline $50^{\circ}$ & 2660 & 1750 & trace & trace & - & - & - & - \\
\hline $65^{\circ}$ & 3810 & 2080 & 0 & trace & 170 & 110 & 3980 & 2190 \\
\hline
\end{tabular}

is found at $20^{\circ}$ where also the maximum of nitrate-nitrogen lies. This relation may form the cause for the high acidity of these samples. The nitrate-nitrogen content is high also in the samples incubated at $65^{\circ}$, thus offering an explanation for their low $\mathrm{pH}$-values. No accumulation of nitrite-nitrogen could be found.

An equal relationship between the incubation temperature and the mobilization of nitrogen can be found also in the BC-peat. However, the rate of the accumulation of mineral nitrogen has been lower than in the SC-peat. This is particularly true of the samples incubated at $20^{\circ}$ and $35^{\circ}$. Probably, the higher cellulose and hemicellulose contents of the $\mathrm{BC}$-peat has been responsible for a more intensive biological immobilization of nitrogen as compared with that which took place in the SC-peat. The lower content of total mineral nitrogen in both the limed series may also have its cause in a more intensive synthesis of new cell substance. The possibility of denitrification must also be taken into consideration, as well as the loss of ammonia by volatilization. The latter mechanism, however, seems to be less important, since the volatilization of ammonia from a medium more acid than $\mathrm{pH} 6.5$ occurs at a very slow rate (14). In addition to these the possible fixation of ammonia as a structural part of humic acids may deserve some attention.

In general, the optimum temperature for nitrification has been found to be between $20^{\circ}$ and $30^{\circ} \mathrm{C}$, while the minimum and maximum temperatures are about $4^{\circ}$ and $40^{\circ} \mathrm{C}$, respectively $(2,8)$. As to the lower temperatures, the results of these experiments agree with the earlier conceptions, but the fairly high content of nitratenitrogen in the samples incubated at $65^{\circ}$ is unexpected. Before further investigations has been made it is unnecessary to pay more attention to the mechanism of nitrateformation at high temperatures. Perhaps also the accumulation of ammonia at $50^{\circ}$ and at $65^{\circ}$ is partly a purely chemical phenomenon. 
Table 2. Nitrogen fractions in the incubated samples

\begin{tabular}{|c|c|c|c|c|c|c|c|c|}
\hline \multirow{3}{*}{$\begin{array}{c}\text { Incubated } \\
\text { at }\end{array}$} & \multirow{2}{*}{\multicolumn{2}{|c|}{ Tot. N \% }} & \multicolumn{2}{|c|}{ Mineral N } & \multicolumn{2}{|c|}{ Insoluble $\mathrm{N}$} & \multicolumn{2}{|c|}{ Soluble org. $\mathrm{N}$} \\
\hline & & & \multicolumn{6}{|c|}{ per cent of tot. $\mathrm{N}$} \\
\hline & 0 & $\mathrm{CaCO}_{3}$ & 0 & $\mathrm{CaCO}_{3}$ & 0 & $\mathrm{CaCO}_{3}$ & 0 & $\mathrm{CaCO}_{3}$ \\
\hline $\begin{array}{l}\text { SC-peat } \\
\text { Original }\end{array}$ & 2.9 & & 1.3 & & 33 & & 66 & \\
\hline $5^{\circ}$ & 2.9 & 2.9 & 2.5 & 2.6 & 32 & 31 & 65 & 67 \\
\hline $20^{\circ}$ & 2.9 & 2.9 & 3.5 & 2.4 & 34 & 31 & 62 & 66 \\
\hline $35^{\circ}$ & 3.0 & 3.0 & 5.0 & 3.8 & 35 & 33 & 60 & 63 \\
\hline $50^{\circ}$ & 3.1 & 3.2 & $(7.3)$ & $(7.7)$ & 34 & 30 & & \\
\hline $65^{\circ}$ & 3.2 & 3.3 & 19.5 & 15.4 & 37 & 37 & 44 & 48 \\
\hline BC-peat & & & & & & & & \\
\hline Original & 2.5 & & 1.5 & & 34 & & 64 & \\
\hline $5^{\circ}$ & 2.7 & 2.7 & 2.5 & 2.2 & 33 & 32 & 64 & 65 \\
\hline $20^{\circ}$ & 2.8 & 2.8 & 1.9 & 1.7 & 33 & 31 & 65 & 67 \\
\hline $35^{\circ}$ & 2.8 & 2.9 & 2.8 & 2.2 & 29 & 32 & 68 & 66 \\
\hline $50^{\circ}$ & 2.9 & 2.9 & $(9.1)$ & $(6.0)$ & 33 & 32 & & \\
\hline $65^{\circ}$ & 3.0 & 3.1 & 13.4 & 7.1 & 34 & 33 & $\tilde{5} 3$ & 60 \\
\hline
\end{tabular}

In the samples incubated at $50^{\circ}$ and $65^{\circ}$ the mineral nitrogen represents a considerable proportion of the total nitrogen (Table 2) It means that under favourable conditions from one tenth to one fifth of the peat nitrogen can be rendered available fairly easily. But also at the lower temperatures, even at $5^{\circ}$, the mineralization of organic nitrogen has not been quite negligible. The part of total nitrogen that exists in insoluble form or in the fraction of the lignin-humic complex is nearly equal in all the samples. The largest amount of nitrogen occurs in hydrolyzable compounds.

Most of the available information in regard to the influence of heat upon soil properties is obtained in connection with soil sterilization experiments. In general it is stated that steaming or dry heating increase the amount of ammonia, but the nitrate-nitrogen content does not change or it may even drop $(4,7,10,11,12)$. Similar results were obtained also in the present experiments. The data in tables 3 and 4 show a marked increase in the ammonia content of both peats, even due to a treatment at temperatures as low as $50^{\circ}$ and $75^{\circ}$. The moist heat brought about a more intensive transformation of nitrogen than the dry heat, as could be expected.

Table 3. $\mathrm{NH}_{4}$-nitrogen and $\mathrm{NO}_{3}$-nitrogen in the peat samples treated by moist heat for two hours. Expressed as ppm of dry matter.

\begin{tabular}{cccccc}
\hline \multirow{2}{*}{ Temperature } & \multicolumn{2}{c}{ SC-peat } & & \multicolumn{2}{c}{ BC-peat } \\
\cline { 2 - 3 } \cline { 5 - 6 } & $\mathrm{NH}_{4}-\mathrm{N}$ & $\mathrm{NO}_{3}-\mathrm{N}$ & & $\mathrm{NH}_{4}-\mathrm{N}$ & $\mathrm{NO}_{3}-\mathrm{N}$ \\
\hline $75^{\circ}$ & 710 & 20 & & 720 & 20 \\
$100^{\circ}$ & 740 & 20 & & 820 & 20 \\
$120^{\circ}$ & 800 & 20 & & 810 & 20 \\
\hline Original & 330 & 30 & 390 & 50 \\
\hline
\end{tabular}


Table 4. $\mathrm{NH}_{4}$-nitrogen and $\mathrm{NO}_{3}$-nitrogen in the peat samples treated by dry heat for three hours. Expressed as ppm of dry matter.

\begin{tabular}{cccccc}
\hline \multirow{2}{*}{ Temperature } & \multicolumn{2}{c}{$\mathrm{SC}$-peat } & & \multicolumn{2}{c}{$\mathrm{BC}$-peat } \\
\cline { 2 - 3 } \cline { 5 - 5 } & 500 & 20 & $\mathrm{NH}_{4}-\mathrm{N}$ & $\mathrm{NO}_{3}-\mathrm{N}$ \\
\hline $50^{\circ}$ & 420 & 20 & & 520 & 20 \\
$75^{\circ}$ & 470 & 20 & & 420 & 20 \\
$100^{\circ}$ & 500 & 20 & 420 & 20 \\
$125^{\circ}$ & 340 & 20 & & 440 & 20 \\
$150^{\circ}$ & 720 & 40 & & 300 & 20 \\
$200^{\circ}$ & 330 & 30 & 650 & 20 \\
\hline Original & & & 390 & 50 \\
\hline
\end{tabular}

It is of interest to note that accumulation of ammonia nitrogen in the samples treated by dry heat does not increase when the temperature increases from $50^{\circ}$ to $125^{\circ}$. At $150^{\circ}$ a drop in the values precedes the maximum of these experiments lying at $200^{\circ}$.

These data for the ammonia and nitrate nitrogen contents of the peat samples cannot, however, give any reliable picture of the transformations brought about by the heat treatments. The losses of organic matter and, particularly, of total nitrogen are more important points. Tables 5 and 6 reveal that these losses were nearly negligible at temperatures below $125^{\circ}$. At $150^{\circ}$ and especially at $200^{\circ}$ a considerable amount of organic matter was burnt up. The losses of total nitrogen at these highest temperatures were about one half of the corresponding decreases in the dry matter. The nitrogen in the $\mathrm{BC}$-peat seems to have been more resistant than that of the SC-sample.

The relations between the losses of nitrogen and organic matter probably depends on the nature and on the degree of decomposition of the peat. For example, in the experiments reported by POTTER and SNYDER (10) the loss of total nitrogen was more than twice as large as that of dry matter when a well-decomposed peat sample was heated at $200^{\circ}$ for two hours.

The changes of acidity deserve some attention. A fairly regular decrease in the

Table 5. Acidity and losses of dry matter and total nitrogen in peat samples treated by moist heat for two hours

\begin{tabular}{|c|c|c|c|c|c|c|}
\hline \multirow[b]{3}{*}{ Temperature } & \multicolumn{3}{|c|}{ SC-peat } & \multicolumn{3}{|c|}{ BC-peat } \\
\hline & \multirow[b]{2}{*}{$\mathrm{pH}$} & \multicolumn{2}{|c|}{ Losses of } & \multirow[b]{2}{*}{$\mathrm{pH}$} & \multicolumn{2}{|c|}{ Losses of } \\
\hline & & $\begin{array}{c}\text { dry } \\
\text { matter } \\
\%\end{array}$ & $\begin{array}{c}\text { tot. } \mathrm{N} \\
\%\end{array}$ & & $\begin{array}{c}\text { dry } \\
\text { matter } \\
\%\end{array}$ & $\begin{array}{c}\text { tot. } \mathrm{N} \\
\%\end{array}$ \\
\hline $75^{\circ}$ & 4.53 & 0 & 0 & 4.91 & 1 & 0 \\
\hline $100^{\circ}$ & 4.41 & 2 & 0 & 4.85 & 1 & 0 \\
\hline $120^{\circ}$ & 4.49 & 1 & 0 & 4.80 & 3 & 0 \\
\hline
\end{tabular}


Table 6. Acidity and losses of diry matter and total nitrogen in peat samples treated by dry heat for three hours.

\begin{tabular}{|c|c|c|c|c|c|c|}
\hline \multirow{3}{*}{ Temperature } & \multicolumn{3}{|c|}{ SC-peat } & \multicolumn{3}{|c|}{ BC-peat } \\
\hline & \multirow[b]{2}{*}{$\mathrm{pH}$} & \multicolumn{2}{|c|}{ Losses of } & \multirow[b]{2}{*}{$\mathrm{pH}$} & \multicolumn{2}{|c|}{ Losses of } \\
\hline & & $\begin{array}{c}\text { dry } \\
\text { matter } \\
\%\end{array}$ & $\begin{array}{c}\text { tot. } \mathrm{N} \\
\% \\
\end{array}$ & & $\begin{array}{c}\text { dry } \\
\text { matter } \\
\% \\
\end{array}$ & $\begin{array}{c}\text { tot. } \mathrm{N} \\
\% \\
\end{array}$ \\
\hline $50^{\circ}$ & 4.92 & 0 & 0 & 5.09 & 0 & 0 \\
\hline $75^{\circ}$ & 4.83 & 0 & 1 & 5.05 & 1 & 0 \\
\hline $100^{\circ}$ & 4.79 & 0 & 4 & 4.96 & 2 & 0 \\
\hline $125^{\circ}$ & 4.62 & 0 & 3 & 4.80 & 2 & 0 \\
\hline $150^{\circ}$ & 4.57 & 13 & 7 & 4.74 & 9 & 2 \\
\hline $200^{\circ}$ & 5.33 & 32 & 17 & 5.80 & 37 & 16 \\
\hline
\end{tabular}

$\mathrm{pH}$-values with increasing temperature can be demonstrated within the range from $50^{\circ}$ to $150^{\circ}$. This is in accordance with several earlier investigations. $(3,6)$, and probably due to changes in the state of peat colloids. At $200^{\circ} \mathrm{C}$, however, the structure of the organic material must have been partly destroyed, and a decrease in the amount of organic acids has brought an increase in the corresponding $\mathrm{pH}-$ values.

\section{Summary and conclusions}

The preliminary experiments the results of which are recorded in the present paper, have been carried out in order to obtain some information on the microbiological and chemical mobilization of peat nitrogen at various temperatures.

In the incubation experiment at $5^{\circ}, 20^{\circ}, 35^{\circ}, 50^{\circ}$, and $65^{\circ} \mathrm{C}$ the accumulation of ammonia nitrogen increased with a rising temperature except in the limed series where a minimum was found at $20^{\circ}$. The maximum of nitrate-nitrogen lay at $20^{\circ}$ in both the series. The amount of nitrite-nitrogen was almost negligible in all the samples.

The mineral nitrogen in the samples incubated at $50^{\circ}$ and $65^{\circ}$ represented $10-20 \%$ of the total nitrogen. Thus, the organic nitrogen in peat soils can be mobilized to a marked extent, if the conditions are favourable. Accumulation of mineral nitrogen could be stated also at the lower temperatures where the reutilization of released nitrogen in the synthesis of new microbial substance is always more intensive than in the range of thermophilic organisms. Even at $5^{\circ}$ a release of nitrogen was noticable.

In these experiments liming did not show any beneficial effect upon the accumulation of mineral nitrogen, on the contrary, the values for total nitrogen and ammonia nitrogen were lower in the limed series. The nitrate formation was generally somewhat higher in the limed samples than in the corresponding unlimed ones.

It was supposed that the considerable increase in the ammonia content of the samples incubated at $50^{\circ}$ and $65^{\circ}$ was partly due to purely chemical transformations, 
since the mere heating of moist samples at $75^{\circ}$ for two hours brought about a marked accumulation of ammonia nitrogen. The treatment with dry heat was less effective except when the temperature was raised to $200^{\circ}$ in which case a carbonization of the peat took place. The losses of organic matter and of total nitrogen due to the heating were almost negligible at the temperatures below $150^{\circ}$. At $150^{\circ}$ and at $200^{\circ}$, respectively, about one tenth and one third of the organic matter was burnt up, and the losses of total nitrogen corresponded to approximately one half of the decrease in dry matter.

On the basis of the results reported above valid conclusions ought not to be drawn, since the material is too scarce. However, these experiments indicate that reasons for further research exist.

\section{REFERENCES}

(1) Berge, T. O. 1941. Determination of nitrate-nitrogen with a photoelectric colorimeter. Soil Sci. 52 , p. $185-191$.

(2) Gerretsen, F. C. 1942. Enkele waarnemingen betreffende den invloed van de temperatuur op de nitrificatie en vastlegging van de stikstof. Landbouwk. Tijdschr. 54, p. 573. Ref. Antonie van Leeuwenhoek 11, p. 115-116.

(3) Huberty, M. R. and HaAs, A. R. C. 1940. The $\mathrm{pH}$ of soil as affected by soil moisture and other factors. Soil Sci. 49, p. $455-478$.

(4) Johnson, J. 1919. The influence of heated soils on seed germination and plant growth. Soil Sci. 7. p. $1-104$.

(5) Kaila, A. 1952. Humification of straw at various temperatures. Acta Agr. Fennica $78^{3}, 32 \mathrm{p}$.

(6) _- - and Ryti, R. 1951. Observations on factors influencing the results of chemical soil tests. Acta Agric. Scandinavica 1, p. 271-281.

(7) Malowany, S. N. and Newton, J. D. 1947. Studies on steam sterilization of soils. I. Canaa. J. Res. C 25, p. 189-208.

(8) Mork, E. 1938. Omsetningen i humusdekket ved forskjellig temperatur og fuktighet. Meddel. Norske Skogsforsøksv. 21, p. 179-224.

(9) Post, L. v. 1924. Das genetische System der organogenen Bildungen Schwedens. Com. Intern. Pédol. IV Comm. 22, p. 287-304.

(10) Potter, R. S. and SNyder, R. S. 1918. The effect of heat on some nitrogenous constituents of soil. Soil Sci. 5, p. 197-212.

(11) Roll-Hansen, J. 1952. Damping av jord til tomat. Forskning og forsok i landbruket 1952, p. $229-257$.

(12) Russell, E. J. and Hutchinson, H. B. 1909. The effect of partial sterilisation of soil on the production of plant food. J. Agric. Sci. 3, p. 111-144.

(13) Springer, U. 1940. Humifizierung und Zersetzung und ihre Bestimmung in Torfen, Stallmisten und anderen organischen Bildungen. Bodenk. u. Pflanzenern. 18, p. 129-167.

(14) Tuorila, P. 1929. Bindungsvermögen verschiedener Torfarten für Stickstoff in Form von Ammoniak. S. Suovilj. yhd. tiet. julk. 9, 47 p.

(15) Waksman, S. A. and Gerretsen, F. C. 1931. Influence of temperature and moisture upon the nature and extent of decomposition of plant residues by microorganisms. Ecology 12, p. $33-60$.

(16) Waksman, S. A., Umbreit, W. W. and Cordon, T. C. 1939. Thermophilic actinomycetes and fungi in soils and composts. Soil 47 , p. $37-61$. 


\title{
SELOSTUS :
}

\section{LÄMPÖTILAN VAIKUTUKSESTA TURPEEN TYPEN MOBILISOITUMISEEN}

\author{
Armi Kaila, JaAkKo Köylijärvi ja Erkki Kivinen \\ Yliopiston maanviljelyskemian laitos, Helsinki
}

Yliopiston maanviljelyskemian laitoksessa käynnissä olevien Pohjois-Suomen soiden typen käyttökelpoisuutta koskevien tutkimusten yhteydessä on kiinnitetty huomiota myös lämpötilan vaikutukseen typen mobilisoitumista säätelevänä tekijänä. Edellä on selostettu eräitä laboratoriokokeita, joilla pyrittiin selvittämään turpeen typen mikrobiologista ja kemiallista mobilisoitumista eri lämpötiloissa.

Kun verraten heikosti maatuneita SC- ja BC-turpeita muhitettiin $100 \mathrm{vrk} .5^{\circ}, 20^{\circ}, 35^{\circ}, 50^{\circ}$ tai $65^{\circ}$ lämpötilassa, todettiin näytteiden ammoniumtypen lisääntyneen sitä enemmän, mitä korkeampi oli muhituslämpötila. Poikkeuksen muodostivat kuitenkin kalkittujen sarjojen $20^{\circ}$ :ssa muhitetut näytteet, joiden ammoniumtypen pitoisuus oli muita alempi. Nitraattityppeä kertyi eniten $20^{\circ}$ :ssa. Nitriittityppeä oli näytteissä häviävän pienet määrät.

Näissä kokeissa ei kalkitus lisännyt näytteiden mineraalitypen määrää, vaan päinvastoin kalkittujen sarjojen ammoniumtypen ja mineraalitypen määrät olivat pienemmät kuin kalkitsemattomien. Korkeampi $\mathrm{pH}$ oli myös edistänyt nitraattitypen muodostumista.

$50^{\circ}$ ja $65^{\circ}$ lämpötiloissa muhitettujen näytteiden mineraalityppi oli $10-20 \%$ näytteiden kokonaistypestä. Alemmissa lämpötiloissa, joissa typen biologinen pidättyminen on voimakkaampaa kuin termofiilien mikro-organismien alueella, oli kertyneen mineraalitypen määrä huomattavasti pienempi, vain muutama prosentti kokonaistypestä.

On todennäköistä, että korkeammissa lämpötiloissa vapautuu ammoniumtyppeä puhtaasti kemiallistenkin tekijöiden vaikutuksesta, sillä pelkkä kosteiden näytteiden kuumentaminen kahden tunnin aikana $75^{\circ}$ :ssa lisäsi huomattavasti ammoniumtypen määrää. Kuivien näytteiden kuumentaminen johti tehokkaaseen ammoniumtypen kertymiseen vasta, kun lämpötila oli $200^{\circ}$, jolloin turve jo melkoisesti hiiltyi ja noin kolmannes sen kuiva-aineesta paloi. Typen häviö tässä lämpötilassa oli vain noin puolet orgaanisen aineksen häviöstä. 